\title{
AN EMPIRICAL STUDY OF LEARNERS OF ENGLISH AND THEIR NEEDS*
}

\author{
Raquel Orgeira Crespo. Universidad de Santiago de Compostela
}

\begin{abstract}
This paper is an attempt to analyse the needs of adult learners enrolled on an English course as part of a pioneer programme developed at University of Santiago de Compostela. I will confine myself to a description of the needs analysis carried out by means of a survey study. I aim at gaining a thorough understanding of the needs of the learners in this course so that teachers could capitalise on that knowledge when designing foreign language curricula. For this purpose, a questionnaire was prepared. The results of the poll should affect the programming of the course in terms of objectives, contents, methods, target skills, materials and assessment.
\end{abstract}

\section{INTRODUCTION}

The increase in life expectancy has prompted institutions, political parties, governments etc. to draw attention to a social group that has been neglected: the elderly. This shift in attitudes has materialised in centres making educational provision for this age group. Thus, universities have started to open the doors to this sector of the population that had been traditionally kept aloof from this level of education. At University of Santiago de Compostela this initiative is named Cuarto Ciclo Universitario and has proved to be very successful. Cuarto Ciclo Universitario is a programme at tertiary level aimed at adults above fifty-five years of age, irrespective of their previous instruction. The major general objective is "potenciar la integración social de las personas mayores en la vida económica, social y cultural, promocionando a este colectivo como una etapa de la vida positiva, digna y capaz" (Mayán Santos et al., 1998: 9). In other words, to avoid social isolation that ageing brings about as well as helping elderly people to cope with a new period of their life. In line with this approach, the only entry requirement is the capacity to pay the fee. Instruction is given by University teaching staff on the premises. The programme spans five years, the first three are general and the other two are aimed at specialisation. There are four areas with their corresponding subjects:

\footnotetext{
* A first version of this paper was presented at the XVIII Congreso de AESLA, held at the university of Barcelona in May 2000. This research has been funded by the Galician Ministry of Education (Secretaría Xeral de Investigación, PGIDT00PXI20407PR). This grant is hereby greatfully acknowledged.
} 
Ciencias de la Salud, Ciencias Experimentales y Técnicas, Ciencias Sociales y Jurídicas and Humanidades. It is in this latter group that English is included. For the time being, the number of hours allocated to English, and to the other subjects as well, is one per week over an academic year, which amounts to roughly thirty hours of tuition as a whole. Since teachers are responsible for laying down curricula and in view of the characteristics of the target student body, I thought that before proceeding to the design of the curriculum it would be advisable to arrive at a deep understanding of the members of the target group. At this point, it is worth establishing what is understood by curriculum. This implies bringing up the concept of syllabus as both notions tend to be mixed up. In the British tradition by syllabus is meant "the content or subject matter of an individual subject" while curriculum is concerned with "the totality of content to be taught and aims to be realised within one school or educational system". On the other hand, in the USA curriculum is often synonymous with syllabus as considered in Britain (White, 1989: 4). Here we will stick to the British differentiation, which considers curriculum as an all-embracing activity encompassing the following elements: objectives, contents, methodology and assessment. In this paper assessment is considered to be "the set of processes by which we judge student learning" (Nunan, 1989: 118). It must not be confused with evaluation, which entails a wider process related to curriculum on a global scale.

In this context, I set out to explore the needs typical of this age group, with the aim of devising a curriculum for the English subject tailor-made for them. This process is known as needs analysis. It is a key element of the curriculum model, as proposed by Taba and Tyler (in White, 1989: 26). Needs analysis could be defined as a means of gathering information about learners meant to be used as a basis for planning. Nunan considers it as "a set of procedures for specifying the parameters of a course of study" (1989: 45). According to Richards et al. diagnose of needs serves to obtain information on

(a) the situations in which a language will be used (including who it will be used with)

(b) the OBJECTIVES and purposes for which the language is needed

(c) the types of communication that will be used (eg written, spoken, formal, informal)

(d) the level of proficiency that will be required. (1985: 189).

Needs analyses were first used in the 1970s. The Council of Europe gave it fresh impetus to such an extent that needs analysis has become the standard previous step in curriculum design. In the learner-centred approach that presently dominates the field of ELT, both learners and their needs must be known and taken into consideration when it comes to design course curriculum. Therefore, firstly those needs have to be defined and secondly, that information will be used for course design. Instruments for drawing up a profile of learners' needs have been devised, being Munby's (1998) one of the most famous. When it is the target group that expresses their needs, these are termed subjective needs, as opposed to objective needs, which are stated by teachers. Consequently, needs analysis turns out to be a preliminary procedure in order to make decisions concerning objectives, contexts, materials, methods of assessment and so on. Thus, the curriculum should be the result of the subjective needs identified by learners plus the general objective needs set by the teacher. In other words, it should derive from the negotiation between the two protagonists of the process of teaching-learning the target language. This implies teachers being ready and willing to accept or negotiate learners' preferences, which should be considered expressions of subjective needs and not attempts to challenge teachers' authority or competence (Brindley, 1989: 75). Finally, the resulting curriculum should be flexible for subjective needs can vary along the learning process (Handt, 1983: 25).

Odisea, $\mathrm{n}^{0} 1,2001$ 
Questions to be asked for a needs analysis are: who will be using English? For what purpose? What topics are to be dealt with? What levels of cultural knowledge are required? What listening, speaking, reading, writing activities? Which spoken and written communicative activities and functions? What medium or combination of media is involved? Which teaching methodology is demanded? Which assessment methods for evaluating academic progress? I sought answers to such questions by means of a survey, which aimed at the definition of needs for elderly learners.

\section{STATEMENT OF PURPOSE}

Assuming that in a learner-centred framework teaching a modern language presupposes identification and analysis of needs so as to develop a negotiated curriculum, I set about carrying out this process for learners of English above fifty-five years of age in tertiary education by means of a cross-sectional study. In view of the fact that we cannot teach the same language and after the same manner to adult groups and young students, the survey attempted to address fundamental questions about objectives, contents, method, materials and assessment required by the target group. The aims were directed at providing a general account of the needs of students aged fifty-five or over and devising a course of English geared to satisfy the specific needs of a particular group of learners, that is, their subjective needs.

In my opinion, this survey might be useful for both learners, because it awakens their awareness, and for teachers, because it gives them a better grasp of their learners and can adapt the teaching accordingly.

\section{METHOD}

Subjects. Eleven students enrolled in English completed the questionnaire. Because they had a wide margin of choice in the subjects which they could take and were not constrained by parental pressure to learn English, the motivation of these learners is expected to be very high. In addition, the majority were likely to have kept aloof from the tertiary level of instruction due to the difficulties for enrolling at university when they were young; being given the opportunity to enter university is very encouraging for them, which results in a more positive attitude towards the learning experience.

They are students above the age of fifty-five. Such a characteristic involves fundamental issues of learning English in relation to age. It is common belief that elderly people are ill equipped to deal with a learning situation. When they retire, they are supposed to begin automatic decrease in their mental and physical powers. Research contradicts this assumption, though. Thus, Zunzunegui carried out a study with 1,300 people above sixty-five years of age and concluded that "el avance de edad no es sólo sinónimo de pérdida de facultades, sino que puede significar recuperación o, al menos, su mantenimiento" (in Mayán Santos et al., 1998: 17). Tamayo even goes further by holding that:

La mente no se atrofia con la edad, todo lo contrario: se hace más lúcida y perspicaz. Se atrofia al no utilizarla. La experiencia es la mejor prueba de ello: hay personas mayores, muy mayores, con una lucidez mental extraordinaria, mientras que hay jóvenes con la mente descargada. (in Mayán Santos et al., 1998: 16) 
Even age may become an asset as these individuals

bring to the task a mature personality, many years of educational training, a developed intelligence, a determination to get what they want, fairly clear aims, and above all strong motivation to make as rapid progress as possible. (Broughton et al., 1988: 187)

In addition, they have accumulated experiences they can capitalise on for learning. In any event, it is as well to remind ourselves that old age is just a chronological reference. Furthermore, no unanimous agreement has been reached on the role of age in the learning of a foreign language. In spite of the fact that several theories have been put forward findings are still inconclusive (Palacios Martínez, 1994: 60). However, on no account should the elderly be banned from learning. Although some abilities may be more limited, learning can still take place in this stage of life. A change in learning strategies will make up for potential loss in the capacity for learning a foreign language.

Materials and Procedures. Needs analysis consists basically in collecting, processing and using the information elicited to develop a learning project. In this particular case, in order to identify students' needs more closely I drew up a questionnaire mainly based on the ones designed by Palacios Martínez (1993). Being a fast and easy means of collecting data, it was considered the most suitable tool for this task.

The questionnaire was devised at the beginning of the course. When preparing the poll, the question arose as to whether participants would be able to express their needs precisely. I thought that students might find it difficult to articulate their needs or simply they might not be aware of them. Moreover, needs "are not fully-developed facts capable of being described in the same way as a house" (Richterich and Chancerel, 1980: 9). It may also happen that learners had only a vague idea, if any, of what they need, that is, they might not describe their needs fairly clearly.

To facilitate the task I singled out the following structure. The questionnaire was made up of thirteen items, all closed questions except the first one. However, in the closed questions blanks were provided to invite learners to refine their answers or add any comment. The items were written in the form of behaviours, for example "I like languages". Very precise information was supplied and unfamiliar terminology was avoided as it could prove confusing to informants (see Appendix 1).

With the purpose of eliciting information about objectives, contents, materials, methods and assessment of the learning programme, the first two questions aimed at establishing the profile and background of learners; these consisted of questions about previous learning experiences in English, length of time spent in the target language and the reasons why they took the subject. The third question concerned the identification of learning goals for the course. Question four dealt with the skills learners would like to improve. Questions five to ten went fully into their preferred contents for the class. Question 11 supplied details on favourite methodology. In question 12, students were asked about the materials preferences. Finally, the last question was designed to elicit the means of assessment learners wished. In my opinion, the questionnaire asked for the necessary information to get an insight into learners' needs.

I piloted the poll with three students. Once the necessary corrections were made, I gave the questionnaire out the first day of the course during class time. Eleven students were present and were urged to answer all the items of the questionnaire as honestly as possible and individually. As an initial warm-up, they had previously been briefed about the purpose of the questionnaire and received instructions on the way of completing it. It was made clear that the poll was 
anonymous. They were asked to rank all the items in order from completely agree (5) to completely disagree (1) and succeeding numbers in descending order by circling the number that best represented their answer. Thus, higher scores indicated greater adherence to the assertions made in the survey.

In the following section a brief attempt will be made to sketch the results that the analysis of the data yielded. They are displayed in tables wherein the degree of endorsement of each item is listed as well as the mean, which indicates the central tendency of the distribution in terms of agreement on the five-point scale.

\section{RESULTS AND DISCUSSION}

Once information was assembled and classified the data were analysed. As the number of them was not large, they were not processed according to statistical techniques. None but one learner added comments or specified an answer other than those already stated in the questionnaire. This can be explained on the grounds that they had little or none experience in completing questionnaires. However, they were able to express their needs, thus confirming Kennedy and Bolitho's statement that "the older a learner is, the more likely he is to have his own definite ideas on why he is learning English" (1990: 13-14).

Firstly, we must determine the target group, that is, what kind of community are we serving? The participants are all over fifty-five years old. The questionnaire revealed that ten students had been schooled in English and only one had not previous knowledge of the language. Among those who did receive instruction in English, they reported the learning experience to have taken place many years ago (one informant said that it had been more than fifty years ago). In addition, the time of instruction had not been very long either, spanning from three months to four years. The locations where they learnt English were secondary schools, language schools and private institutions. These results show that the degree of homogeneity within the class was rather high derived from the fact that the learners of this study began with a very rusty knowledge of the English they did many years before.

Question two attempted to discover what were the reasons for the choice. This is a key consideration in defining the components of a curriculum. Ratings are broken down in Table 1.

Table 1 Reasons for studying English

\begin{tabular}{|c|c|c|c|c|c|c|}
\hline Question 2 & $\begin{array}{l}\text { Complete } \\
\text { ly agree }\end{array}$ & Agree & Neutral & Disagree & $\begin{array}{c}\text { Completely } \\
\text { disagree }\end{array}$ & Mean \\
\hline I like languages & 6 & 3 & 1 & & 1 & 4.18 \\
\hline To travel abroad & 4 & 1 & 3 & 2 & 1 & 3.45 \\
\hline $\begin{array}{l}\text { To write more fluent \& correct } \\
\text { English }\end{array}$ & 6 & 1 & 2 & 1 & 1 & 3.90 \\
\hline Not having learnt before & 1 & 2 & 2 & & 6 & 2.27 \\
\hline $\begin{array}{l}\text { To improve previous } \\
\text { knowledge }\end{array}$ & 4 & 3 & 3 & & 1 & 3.81 \\
\hline Easy subject & & & 3 & 3 & 4 & 1.9 \\
\hline Followed advice & & & & 1 & 10 & 1.09 \\
\hline $\begin{array}{l}\text { Not able to choose another } \\
\text { subject }\end{array}$ & 1 & 1 & 1 & 2 & 6 & 2 \\
\hline
\end{tabular}


They rated higher (in decreasing order): liking for languages, to write in English more fluently and correctly and to improve previous knowledge, reasons denoting an integrative motivation. The lowest ratings corresponded to the following items: to travel to a foreign country, not having had the chance of learning English before, to find English easy, having followed advice and not being able to choose another subject. As far as travelling is concerned, it is likely that health, family or economic resources prevent some of them from spending time abroad. None of the participants considered English an easy subject to learn, clearly due to the long-standing bad reputation of English pronunciation. The last two items are not discussed as they do not lend themselves to interpretations.

The data I sought to obtain by means of question three involved the objectives learners wished to attain. As Table 2 shows, all of them pointed out that one of the main objectives should be to acquire a working knowledge of spoken and written English. Next, they viewed the study of English as a means of filling a gap in education or as an extension of it, which is in line with answers to question one wherein most of them acknowledged to have acquired the rudiments of English. It is notable that most of them showed slight interest in getting to know deeply English or American culture. Taking into consideration that the question was directed at pointing out the major objectives, it is a sweeping assumption to state that the vast majority dismiss cultural knowledge at all; rather the most reasonable conclusion to be drawn boils down to an emphasis in learning the English language as a primary goal. One person added that one of the objectives of the course should be aimed at understanding simple and nonspecialised texts, which roughly amounts to the first one already mentioned.

Table 2 Objectives

\begin{tabular}{|c|c|c|c|c|c|c|}
\hline Question 3 & $\begin{array}{c}\text { Completely } \\
\text { agree }\end{array}$ & Agree & Neutral & Disagree & $\begin{array}{c}\text { Completely } \\
\text { disagree }\end{array}$ & Mean \\
\hline $\begin{array}{c}\text { Gain working } \\
\text { knowledge }\end{array}$ & 9 & 2 & & & & 4.81 \\
\hline $\begin{array}{l}\text { English /American } \\
\text { culture }\end{array}$ & 1 & 1 & 6 & 1 & 2 & 2.81 \\
\hline Complete education & 3 & 3 & 2 & & 3 & 3.27 \\
\hline
\end{tabular}

It is essential to know which communicative skills (reading, writing, listening, speaking) are most relevant and important for the students. Responses to this were provided by question four.

Table 3 Communicative skills

\begin{tabular}{|l|c|c|c|c|c|c|}
\hline \multicolumn{1}{|c|}{ Question 4 } & $\begin{array}{c}\text { Completely } \\
\text { agree }\end{array}$ & Agree & Neutral & Disagree & $\begin{array}{c}\text { Completely } \\
\text { agree }\end{array}$ & Mean \\
\hline $\begin{array}{l}\text { Written } \\
\text { comprehension }\end{array}$ & 7 & 4 & & & & 4.63 \\
Oral & 8 & 3 & & & 4.72 \\
$\begin{array}{c}\text { comprehension } \\
\text { Written expression } \\
\text { Oral expression }\end{array}$ & 5 & 4 & 1 & 1 & & 4.18 \\
\hline
\end{tabular}

Odisea, $n^{0} 1,2001$ 
As Table 3 reveals, the four skills were given more or less equal weighting, a fact indicating that participants perceived it necessary to achieve uniformity in all of them.

Learners' answers from questions five to ten provided material to map out the contents of the course. Question five tried to elicit what type of activities learners considered best adapted to them. As revealed by Table 4, the results show that the students surveyed rated highly the following activities: teacher's formal explanations, pronunciation exercises, listening activities by means of tapes, reading newspapers and magazines and text-translating. Low percentages of agreement for role-play and listening to songs were expected as older people are not usually fond of acting or similar activities that probably conflict with the notion they hold of learning and teaching.

Table 4 Activities

\begin{tabular}{|l|c|c|c|c|c|c|}
\hline \multicolumn{1}{|c|}{ Question 5 } & $\begin{array}{c}\text { Completely } \\
\text { agree }\end{array}$ & Agree & Neutral & Disagree & $\begin{array}{c}\text { Completely } \\
\text { disagree }\end{array}$ & Mean \\
\hline Listening to tapes & 5 & 5 & 1 & & & 4.36 \\
Grammar tasks & 2 & 3 & 5 & & & 3.70 \\
Conversations \& & 2 & 4 & 3 & 2 & & 3.54 \\
$\quad$ debates & & 1 & 6 & 1 & 3 & 2.45 \\
Role-play & 4 & 5 & 2 & & & 4.18 \\
Translating texts & 3 & 3 & 4 & 1 & & 3.72 \\
Writing letters \& other & & & & & & \\
$\quad$ texts & 4 & 7 & & & & 4.36 \\
Reading papers \& & & & & & & \\
$\quad$ magazines & 7 & 3 & 1 & & & 4.81 \\
Teacher's explanations & 9 & 2 & & & & \\
Pronunciation tasks & 1 & 2 & 4 & 2 & 2 & 2.81 \\
Listening to songs & 2 & 1 & 3 & 2 & 3 & 2.72 \\
Discussing cultural & & & & & & \\
\hline topics & & &
\end{tabular}

The issue of what topics they wanted the course encompassed was addressed in question six. In explaining their preferences, participants rated higher personal relationships and nature, as expressed in Table 5. Both culture and life of English-speaking countries and work were other frequently mentioned activities considered interesting for the English class. Personal experiences, movies and television, music, sports and entertainments and ageing were among the least interesting topics. 
Table 5 Topics

\begin{tabular}{|c|c|c|c|c|c|c|}
\hline Question 6 & $\begin{array}{c}\text { Complete } \\
\text { ly agree }\end{array}$ & Agree & Neutral & Disagree & \begin{tabular}{|c|} 
Completely \\
disagree
\end{tabular} & Mean \\
\hline Current affairs & 3 & 3 & 4 & & 1 & 3.63 \\
\hline $\begin{array}{l}\text { Culture/life of English } \\
\text { speaking countries }\end{array}$ & 2 & 7 & 1 & 1 & & 3.90 \\
\hline Personal experiences & 2 & 1 & 6 & 1 & 1 & 3.18 \\
\hline Cinema \& television & & 1 & 6 & 2 & 2 & 2.54 \\
\hline Holidays and journeys & 3 & 4 & 2 & & 2 & 3.54 \\
\hline Nature & 3 & 7 & 1 & & & 4.18 \\
\hline Music & 2 & 2 & 5 & 1 & 1 & 3.27 \\
\hline Fashion & & & 4 & & 6 & 1.80 \\
\hline $\begin{array}{l}\text { Sports \& } \\
\text { entertainments }\end{array}$ & 2 & 2 & 4 & 1 & 2 & 3.09 \\
\hline Politics & 2 & 4 & 3 & 1 & 1 & 3.45 \\
\hline Ageing & & 2 & 4 & 2 & 3 & 2.45 \\
\hline Work & 1 & 8 & 1 & & 1 & 4.09 \\
\hline Personal relationships & 5 & 3 & 3 & & & 4.18 \\
\hline
\end{tabular}

Question seven attempted to find out what type of reading activities learners would prefer to engage in. The results showed in Table 6 point out that they would like to understand signals and warnings, instructions, newspapers, restaurant menus, maps and travel brochures. These tasks have an evident practical use, thus revealing elderly people as fairly realistic subjects. Accordingly, literary texts and magazines obtained the worst results.

Table 6 Written comprehension activities

\begin{tabular}{|l|c|c|c|c|c|c|}
\hline \multicolumn{1}{|c|}{ Question 7 } & $\begin{array}{c}\text { Completely } \\
\text { agree }\end{array}$ & Agree & Neutral & Disagree & $\begin{array}{c}\text { Completely } \\
\text { disagree }\end{array}$ & Mean \\
\hline Literary texts & 3 & 3 & 3 & 2 & & 3.63 \\
Magazines & 2 & 2 & 7 & & & 3.54 \\
Signals \& & 5 & 6 & & & & 4.45 \\
warnings & & & & & & \\
Instructions & 7 & 4 & & & & 4.63 \\
Travel & 7 & 2 & 2 & & & 4.45 \\
brochures & & & & & & \\
Newspapers & 5 & 6 & & & & 4.45 \\
Maps & 4 & 5 & 2 & & & 4.18 \\
Menus & 4 & 6 & 1 & & & 4.27 \\
\hline
\end{tabular}

Odisea, $n^{0} 1,2001$ 
Concerning the reading tasks they would like to be able to perform, writing letters, filling forms, translating a text and drawing up texts ranked high. This choice indicates those tasks are the ones perceived as more useful and attractive. They are not very keen on writing summaries and reports as most of them are retired, thereby not considering those activities as necessary or interesting. These results corresponded to question eight and are displayed in Table 7.

Table 7 Written expression activities

\begin{tabular}{|l|c|c|c|c|c|c|}
\hline \multicolumn{1}{|c|}{ Question 8 } & $\begin{array}{c}\text { Completely } \\
\text { agree }\end{array}$ & Agree & Neutral & Disagree & $\begin{array}{c}\text { Completely } \\
\text { disagree }\end{array}$ & Mean \\
\hline Writing letters & 7 & 4 & & & & 4.63 \\
Filling forms & 7 & 4 & & & & 4.63 \\
Drawing up texts & 5 & 4 & 1 & 1 & & 4.18 \\
Translating texts & 7 & 4 & & & & 4.63 \\
Writing & 3 & 3 & 2 & 1 & 2 & 3.36 \\
summaries & 2 & 2 & 4 & 1 & 2 & 3.09 \\
Writing reports & 2 & & & & & \\
\hline
\end{tabular}

In question nine they were required to express what kind of input they preferred to manage to comprehend. Answers are represented in Table 8.

Table 8 Aural comprehension activities

\begin{tabular}{|l|c|c|c|c|c|c|}
\hline \multicolumn{1}{|c|}{ Question 9 } & $\begin{array}{c}\text { Completely } \\
\text { agree }\end{array}$ & Agree & Neutral & Disagree & $\begin{array}{c}\text { Completely } \\
\text { disagree }\end{array}$ & Mean \\
\hline Instructions & 7 & 4 & & & & 4.63 \\
Songs & 2 & 2 & 5 & & 4 & 2.45 \\
Films & 5 & 6 & & 3 & 1 & 3.18 \\
Warnings & 5 & 3 & 1 & 2 & & 4.45 \\
TV programmes & 5 & 3 & 2 & & & 4 \\
Info. by police, & & & & & & 4 \\
etc. & & & & & & \\
\hline
\end{tabular}

Students' responses revealed a marked interest in understanding instructions to get somewhere, warnings, television programmes and information produced by police officers, waiters, etc. Songs and films have a minor presence probably on the strength of their little practical use for this age group.

Concerning the output they would like to get to produce (question ten), none of the items was given significant priority, rather all of them were highly valued by participants. In fact, they were expected to be interested in learning as many linguistic functions as they could. 
Table 9 Oral expression activities

\begin{tabular}{|l|c|c|c|c|c|c|}
\hline \multicolumn{1}{|c|}{ Question 10 } & $\begin{array}{c}\text { Completely } \\
\text { agree }\end{array}$ & Agree & Neutral & Disagree & $\begin{array}{c}\text { Completely } \\
\text { disagree }\end{array}$ & Mean \\
\hline Asking addresses & 7 & 4 & & & & 4.63 \\
Asking time & 7 & 4 & & & & 4.63 \\
Asking for sth. in & 9 & 2 & & & & 4.81 \\
shop/ restaurant & & & & & & \\
Asking prices & 7 & 3 & 1 & & & 4.54 \\
Providing information & 7 & 2 & 1 & & 1 & 4.27 \\
on self & & & & & & \\
\hline
\end{tabular}

As for the preferable methodology to be used in the English class, data provided by informants out of question eleven disclosed that learners favour teacher's handouts, taking notes, listening to tapes, copying from the blackboard and repetition work, as Table 10 points out. Both learning by heart and searching for information stood out for its low frequency of acceptance, particularly the second item. These are not unexpected results if the participants' age is taken into account. They probably do not rely on their mental abilities, and hence memorising would impose great strain on them, which brings us again to the trite truism that deems old age synonymous with incapacity to tackle learning, especially of a foreign language. I will not pursue this issue now since it has already been discussed before. Rejection to autonomous learning can be explained in terms of lack of time and/or resources.

Table 10 Methodology

\begin{tabular}{|c|c|c|c|c|c|c|}
\hline Question 11 & $\begin{array}{c}\text { Completely } \\
\text { agree }\end{array}$ & Agree & Neutral & Disagree & $\begin{array}{c}\text { Completely } \\
\text { disagree }\end{array}$ & Mean \\
\hline Learning by heart & & 4 & 4 & 3 & & 3.09 \\
\hline Repeating & 6 & 2 & 2 & 1 & & 4.18 \\
\hline $\begin{array}{l}\text { Listening and noting } \\
\text { down }\end{array}$ & 7 & 4 & & & & 4.63 \\
\hline Copying & 4 & 4 & 2 & 1 & & 4 \\
\hline Listening to tapes & 3 & 6 & 1 & 1 & & 4 \\
\hline Handouts & 7 & 4 & & & & 4.63 \\
\hline $\begin{array}{l}\text { Looking for info. } \\
\text { myself }\end{array}$ & 2 & & 3 & 1 & 4 & 2.50 \\
\hline
\end{tabular}

Materials are also important elements in the curriculum in that they turn out to be "the tangible manifestation of the curriculum in action" (Nunan, 1989: 98). The distribution of materials can be appraised in Table 11 . 
Table 11 Materials

\begin{tabular}{|l|c|c|c|c|c|c|}
\hline \multicolumn{1}{|c|}{ Question 12 } & $\begin{array}{c}\text { Completely } \\
\text { agree }\end{array}$ & Agree & Neutral & Disagree & $\begin{array}{c}\text { Completely } \\
\text { disagree }\end{array}$ & Mean \\
\hline $\begin{array}{l}\text { Primary/Secondary } \\
\text { School textbooks }\end{array}$ & & 2 & 4 & 2 & 2 & 2.60 \\
Textbooks for 4 ${ }^{\mathbf{0}}$ Ciclo & 8 & 2 & 1 & & & 4.63 \\
pupils & 3 & 5 & 1 & 1 & & 4 \\
Video & 4 & 5 & 1 & & & 4.30 \\
Tapes & 1 & 1 & 6 & 1 & 1 & 3 \\
Computers & 7 & 4 & & & & 4.63 \\
Teacher's notes & & & & & \\
\hline
\end{tabular}

As can be gathered from the table, replies to question twelve indicated that learners seemed to opt for traditional learning materials such as notes produced by the teacher, specific textbooks and to a lesser extent video and tapes. They depend too much on the teacher since they rated highly materials drawn up by the teacher. A tentative explanation for this selection alludes to the fact that when they studied, the prevailing teaching method was not learnercentred so that the teacher played a major role in the classroom and the whole process turned on $\mathrm{him} / \mathrm{her}$. The use of primary or secondary school textbooks was ruled out. This fact seems to indicate that they probably have an intuitive feeling that materials suitable for young students might not be fitting for them. Computer-aided teaching was also rejected as they are not likely to know how to operate them.

Finally, question thirteen tried to elicit information about what methods of assessment learners wanted to see used. As can be gathered from Table 12, participants preferred monitoring through the course rather than the test at the end. Oral examination received very low ratings as well. The underlying belief these data reveal is that the single examination system seems an inadequate and unfair method for judging academic performance.

Table 12 Assessment

\begin{tabular}{|l|c|c|c|c|c|c|}
\hline \multicolumn{1}{|c|}{ Question 13 } & $\begin{array}{c}\text { Completely } \\
\text { agree }\end{array}$ & Agree & Neutral & Disagree & $\begin{array}{c}\text { Completely } \\
\text { disagree }\end{array}$ & Mean \\
\hline Final written exam & 1 & 2 & 6 & 1 & 1 & 3.09 \\
Final oral exam & 9 & 2 & & & 4 & 2.54 \\
Monitoring during & & & & & & 4.81 \\
course & & & & & & \\
\hline
\end{tabular}

Once data have been interpreted and appraised, the information elicited having common priority can form the basis for the curriculum. A caveat, however, may not be displaced here: the elements of the curriculum should not be considered definite as new needs might arise along the teaching-learning process. 


\section{CONCLUSIONS}

In this paper an attempt was made to identify and describe the target group's needs with the aim of reaching a useful and accurate understanding of learners. The tool singled out for obtaining information was a survey, which provided a quantity of data that were subsequently analysed. This allowed me to establish a profile of needs. It is undeniable that the study provided provisional data that should be confirmed with a larger group of informants, but all the same they might serve as a guide.

The empirical study reported showed that most students were hazy about English. Only one student started from scratch. This means that learners have a reasonably uniform level of English, which is undoubtedly an advantage.

Based on consideration of the reasons for choosing English, these individuals turn out to be highly motivated. Their motivation is, to a large extent, integrative since a liking for languages is claimed to be the main reason for studying English. Furthermore, it was intrinsic since the source of motivation aroused from themselves, not from other people. The teacher, therefore, should channel this motivation in order to obtain optimum learning.

The main objective they set for the course was to develop communicative competence in English. Moreover, from the results obtained follows that the four skills are equally significant for them. Hence, the sort of English they need is a general grounding in English with emphasis on the four skills.

The skills they need will be turned into specific activities. Among these, learners opted for an array of very diverse tasks such as reading newspapers and magazines, teacher's explanations, pronunciation exercises, listening to tapes and translating texts. Due to the variety, no pattern could be identified.

The survey revealed that the favourite topics of the group are personal relationships and nature, although they showed a moderate interest in culture and life of English-speaking countries and work. Despite the fact that the majority of students are retired, it is natural they like to talk about their jobs or previous occupations.

The tasks connected with the four skills they would like to be able to produce and understand showed participants as very pragmatic individuals who prefer to apply their knowledge to deal efficiently with problems in real life, real situations and events.

The favourite methods selected have to do with learning and teaching habits typical of outof-date approaches. The teacher should be respectful with students' learning patterns to a certain extent; in addition, elderly people require a different teaching strategy from that used with younger age groups.

The realisation that the most traditional materials stood out for their high frequency of appearance was one of the insights provided by needs analysis. This results from the type of pedagogy employed when they studied in their youth.

As far as assessment is concerned, standardised methods connected with examinations at the end of the course were greatly dismissed. Considering the widespread rejection of the traditional system, the teacher should place emphasis on formative assessment by means of continuous monitoring throughout the year in the form of assignments to be done at home or in the classroom on a regular basis.

Some results clash with a communicative approach of learning, what may derive from the traditional instruction these students received in their youth as stated above. This could be resolved by allowing for this kind of 'traditional' activities to a rather limited extent. 
The survey conducted provided useful information for course planning on subjective needs and gave the teacher a deep understanding of the make-up of learners. Now a plan for the course can be designed taking into account learners' needs along with other factors such as time limitations. It stands to reason that it is not possible to meet the needs of all learners, rather a selection of the most outstanding ones will be taken. A curriculum prepared on these terms should be most attractive to pupils because presumably they would learn the skills and contents they themselves considered useful and interesting. The contents will be perceived as more relevant insofar as they have been derived from learners' preferences, what presumably will increase motivation and foster positive attitudes. Nevertheless, the curriculum is a dynamic element in that its design does not end once learners' needs have been identified; rather, it is an on-going process that may require modifications along the course. It is possible that learners' needs change while they are learning. Moreover, the curriculum should be flexible; in other words, it must let both teachers and learners freedom for adaptation, improvisation and growth.

\section{REFERENCES}

Brindley, G. 1989. "The role of needs analysis in adult ESL programme design". The Second Language Curriculum. Ed. R. K. Johnson. Cambridge: Cambridge University Press. 63-78.

Broughton, G., Brumfit, C., Flavell, R., Hill, P. and Picas, A. 1988. Teaching English as a Foreign Language. London: Routledge and Kegan Paul.

Handt, G. von der. 1983. "Needs identification and curricula with particular reference to German and migrant workers". Case Studies in Identifying Language Needs. Ed. R. Richterich. Oxford: Pergamon Press. 24-38.

Johnson, R. K., ed. 1989. The Second Language Curriculum. Cambridge: Cambridge University Press.

Kennedy, C. and Bolitho, R. 1990. English for Specific Purposes. London: Macmillan Publishers.

Mayán Santos, J. M. et al. 1999. Cuarto Ciclo Universitario: Formación de Mayores. Santiago de Compostela: Universidad de Santiago de Compostela.

Munby, J. 1998 (1978). Communicative Syllabus Design: A Sociolinguistic Model for Defining the Content of Purpose-specific Language Programmes. Cambridge: Cambridge University Press.

Nunan, D. 1989. The Learner-Centred Curriculum: A Study in Second Language Teaching. Cambridge: Cambridge University Press.

Palacios Martínez, I. 1993. An Analysis and Appraisal of the Situation of ELF Teaching in Spain in Secondary and Tertiary Institutions from the Perspectives of Teachers and Learners. Doctoral Dissertation. Santiago de Compostela: Universidad de Santiago de Compostela.

.1994. "The problem of age in the learning of a foreign language revisited: the new situation in Spain". English Language Teaching in Spain 2: 57-64.

Richards, J., Platt, J. and Weber, H. 1985. Longman Dictionary of Applied Linguistics. Harlow: Longman. 
Richterich, R. and Chancerel, J. L. 1980. Identifying the Needs of Adults Learning a Foreign Language. Oxford: Pergamon Press.

Richterich, R., ed. 1983. Case Studies in Identifying Language Needs. Council of Europe. Oxford: Pergamon Press.

White, R. V. 1989. The ELT Curriculum: Design, Innovation and Management. Oxford: Basil Blackwell.

\section{APPENDIX 1 \\ CUESTIONARIO PARA ALUMNOS DE INGLÉS DE CUARTO CICLO}

Estamos interesados en obtener algunos datos relacionados con la enseñanzaaprendizaje de la lengua inglesa en el nivel de Cuarto Ciclo Universitario. Le agradeceríamos que contestara a este cuestionario con absoluta sinceridad. No existen respuestas correctas o incorrectas.

\section{Nota: Esta encuesta es totalmente anónima.}

1. ¿Tenía conocimientos previos de lengua inglesa antes de iniciar el curso de Cuarto Ciclo? Si es así, ¿dónde los había adquirido, cuándo y durante cuánto tiempo?

Para las preguntas siguientes, rodee con un círculo el número de la columna que mejor exprese su opinión.

5. Totalmente de acuerdo

4. De acuerdo

3. Neutro

2. En desacuerdo

1. En desacuerdo absoluto

2. ¿Qué razones motivaron su elección de inglés en lugar de otras materias?

-Me gustan las lenguas en general

-Me gustaría viajar a un país extranjero

-Escribir en inglés con más fluidez y corrección

-No haber tenido la oportunidad de aprenderlo antes

-Ampliar los conocimientos que ya poseía

-Pensé que sería una asignatura fácil en relación a otras

-Por consejo de otros compañeros

-Porque no pude escoger otra materia

-Otras

$\begin{array}{ccccc}5 & 4 & 3 & 2 & 1 \\ 5 & 4 & 3 & 2 & 1 \\ 5 & 4 & 3 & 2 & 1 \\ 5 & 4 & 3 & 2 & 1 \\ 5 & 4 & 3 & 2 & 1 \\ 5 & 4 & 3 & 2 & 1 \\ 5 & 4 & 3 & 2 & 1 \\ 5 & 4 & 3 & 2 & 1 \\ & & & \end{array}$


3. ¿Cuáles deberían ser, a su juicio, los principales objetivos de este curso?

-Adquirir conocimientos básicos de inglés escrito y hablado5 -Conocer profundamente la cultura inglesa y/o americana 5

-Estar más formado como persona

-Otros

$\begin{array}{cccc}4 & 3 & 2 & 1 \\ 4 & 3 & 2 & 1 \\ 4 & 3 & 2 & 1 \\ & & & \text { (especificar) }\end{array}$

4. ¿Qué destrezas le gustaría mejorar?

-Comprensión de textos escritos (leer)

-Comprensión de mensajes orales (escuchar)

-Expresión escrita (escribir)

-Expresión oral (hablar)

$\begin{array}{lllll}5 & 4 & 3 & 2 & 1 \\ 5 & 4 & 3 & 2 & 1 \\ 5 & 4 & 3 & 2 & 1 \\ 5 & 4 & 3 & 2 & 1\end{array}$

5. ¿Qué actividades le gustaría que se llevaran a cabo en la clase de inglés?

-Escuchar cintas

-Hacer ejercicios de gramática

-Conversaciones y debates

-Juegos de roles

-Traducir textos

-Redactar cartas y textos diversos

-Leer periódicos y revistas

-Explicaciones del profesor

-Ejercicios de pronunciación

-Escuchar canciones

-Discutir aspectos culturales

-Otras

$\begin{array}{ccccc}5 & 4 & 3 & 2 & 1 \\ 5 & 4 & 3 & 2 & 1 \\ 5 & 4 & 3 & 2 & 1 \\ 5 & 4 & 3 & 2 & 1 \\ 5 & 4 & 3 & 2 & 1 \\ 5 & 4 & 3 & 2 & 1 \\ 5 & 4 & 3 & 2 & 1 \\ 5 & 4 & 3 & 2 & 1 \\ 5 & 4 & 3 & 2 & 1 \\ 5 & 4 & 3 & 2 & 1 \\ 5 & 4 & 3 & 2 & 1 \\ & & & \end{array}$

6. ¿Qué temas le interesan más para tratar en la clase de inglés?

-Eventos del día

-Cultura y vida de países de habla inglesa

-Experiencias personales

-Cine y televisión

-Vacaciones y viajes

-Naturaleza

-Música

-Moda

-Deportes y entretenimientos

-Política

-Envejecimiento

-Trabajo

-Relaciones personales

-Otros

$\begin{array}{ccccc}5 & 4 & 3 & 2 & 1 \\ 5 & 4 & 3 & 2 & 1 \\ 5 & 4 & 3 & 2 & 1 \\ 5 & 4 & 3 & 2 & 1 \\ 5 & 4 & 3 & 2 & 1 \\ 5 & 4 & 3 & 2 & 1 \\ 5 & 4 & 3 & 2 & 1 \\ 5 & 4 & 3 & 2 & 1 \\ 5 & 4 & 3 & 2 & 1 \\ 5 & 4 & 3 & 2 & 1 \\ 5 & 4 & 3 & 2 & 1 \\ 5 & 4 & 3 & 2 & 1 \\ 5 & 4 & 3 & 2 & 1 \\ & & & \text { (especificar) }\end{array}$


7. ¿Qué tipo de textos le gustaría ser capaz de leer y comprender en inglés?

-Textos literarios

-Revistas

-Señales y avisos

-Instrucciones

-Folletos turísticos

-Periódicos

-Mapas

-Cartas de restaurante

-Otros

$\begin{array}{ccccc}5 & 4 & 3 & 2 & 1 \\ 5 & 4 & 3 & 2 & 1 \\ 5 & 4 & 3 & 2 & 1 \\ 5 & 4 & 3 & 2 & 1 \\ 5 & 4 & 3 & 2 & 1 \\ 5 & 4 & 3 & 2 & 1 \\ 5 & 4 & 3 & 2 & 1 \\ 5 & 4 & 3 & 2 & 1 \\ & & & \end{array}$

8. ¿Qué tipo de tareas escritas le gustaría ser capaz de hacer en inglés?

-Escribir cartas

-Rellenar impresos

-Redactar un texto

- Traducir un texto

-Escribir resúmenes

-Redactar informes

-Otras

$\begin{array}{ccccc}5 & 4 & 3 & 2 & 1 \\ 5 & 4 & 3 & 2 & 1 \\ 5 & 4 & 3 & 2 & 1 \\ 5 & 4 & 3 & 2 & 1 \\ 5 & 4 & 3 & 2 & 1 \\ 5 & 4 & 3 & 2 & 1 \\ & & & & \end{array}$

9. ¿Qué tipo de cosas le gustaría ser capaz de entender en inglés?

-Direcciones para llegar a un lugar

-Canciones

-Películas

-Avisos en una estación de tren, aeropuerto

-Programas de televisión, informativos

-Información proporcionada por un policía, camarero, etc. 5

-Otras

$\begin{array}{ccccc}5 & 4 & 3 & 2 & 1 \\ 5 & 4 & 3 & 2 & 1 \\ 5 & 4 & 3 & 2 & 1 \\ 5 & 4 & 3 & 2 & 1 \\ 5 & 4 & 3 & 2 & 1 \\ 5 & 4 & 3 & 2 & 1 \\ & & & & \text { (especificar) }\end{array}$

10. ¿Qué cosas le gustaría ser capaz de decir en inglés?

-Preguntar direcciones

-Preguntar la hora

-Pedir algo en una tienda o restaurante

-Preguntar precios

-Dar información sobre uno mismo

-Otras

$\begin{array}{ccccc}5 & 4 & 3 & 2 & 1 \\ 5 & 4 & 3 & 2 & 1 \\ 5 & 4 & 3 & 2 & 1 \\ 5 & 4 & 3 & 2 & 1 \\ 5 & 4 & 3 & 2 & 1 \\ & & & & \end{array}$


11. ¿Cuál es la forma en que le gustaría aprender inglés?

-Memorizando

-Repitiendo lo que oye

-Escuchando y tomando notas

-Copiando del encerado

-Escuchando cintas

-Con esquemas que reparte el profesor

-Buscando información por su cuenta

-Otras

$\begin{array}{ccccc}5 & 4 & 3 & 2 & 1 \\ 5 & 4 & 3 & 2 & 1 \\ 5 & 4 & 3 & 2 & 1 \\ 5 & 4 & 3 & 2 & 1 \\ 5 & 4 & 3 & 2 & 1 \\ 5 & 4 & 3 & 2 & 1 \\ 5 & 4 & 3 & 2 & 1 \\ & & & \end{array}$

12. ¿Qué materiales le gustaría que se emplearan en la clase de inglés?

-Libros de texto de colegios, institutos, etc.

-Libros de texto diseñados para alumnos de $4^{\circ}$ Ciclo

$\begin{array}{ccccc}5 & 4 & 3 & 2 & 1 \\ 5 & 4 & 3 & 2 & 1 \\ 5 & 4 & 3 & 2 & 1 \\ 5 & 4 & 3 & 2 & 1 \\ 5 & 4 & 3 & 2 & 1 \\ 5 & 4 & 3 & 2 & 1 \\ & & & & \end{array}$

-Vídeos

-Cintas de casete

-Ordenadores

-Apuntes elaborados por el profesor

-Otros

(especificar)

13. ¿Cómo le gustaría que el profesor valorara su rendimiento en la asignatura de inglés?

-Por medio de un examen escrito al final del curso

-Por medio de un examen oral al final del curso

$\begin{array}{lllll}5 & 4 & 3 & 2 & 1 \\ 5 & 4 & 3 & 2 & 1 \\ 5 & 4 & 3 & 2 & 1\end{array}$

-Haciendo un seguimiento continuo del alumno a través

de tareas escritas y orales durante todo el curso

-Otros (especificar)

Gracias por su colaboración. Si desea añadir algún comentario, hágalo por favor en el siguiente espacio. 